\title{
NEEDS ANALYSIS OF ENGLISH LEARNING FOR STUDENTS OF ECONOMIC AND BUSINESS UDAYANA UNIVERSITY
}

\author{
Made Detriasmita Saientisna \\ Faculty of Economic dan Business, Udayana University
}

saientisna@gmail.com

\begin{abstract}
To face the Asian Economic Community, mastering English is very important so that people can compete with good workers from their own country or workers from other Asian countries. This study aims to find out (1) what are the problems faced by the students of the Faculty of Economics, Udayana University in learning English and (2) to know the English language needs needed by economic students at the Faculty of Economics and Business, Udayana University. Analysis of English language needs is done by giving questionnaires to students for them to answers, those questions concerning which field of English they are very proficient (speaking, listening, reading and writing) and which areas of English they find it difficult to learn, and choose what lessons they think are necessary which have not been provided in the current syllabus. The answers from these students will be analyzed according to the need analysis by Hutchinson and Waters (1994) and Dudley-Evans and St. John (1998). From this research, it is expected that students can improve their English language skills in economics.
\end{abstract}

Keywords: needs analysis, English, economics, ESP

\section{INTRODUCTION}

At present English can be called as the 'language of the world' because almost $70 \%$ of the world's population can master English actively or passively. In Indonesia, the needs for English is very high, this is proven by the many private companies and even government agencies demanding that employees or prospective employees have a TOEFL test result, namely the English Language Competence Test. This is clearly seen because Indonesia will enter a new phase in the economy, becoming the member of the Asean Economic Community where mastering English is the main requirement.

This phenomenon is recognized by universities in Indonesia, in order to face the globalization era, English is taught as one of the compulsory subjects for students in all faculties in Indonesia. At Udayana University, English courses are compulsory subjects that students must take in the first and second semester and these are applied in all faculties with various departments, one of which is the Faculty of Economics and Business. English language learning that suits the needs of students is very important to be implemented at the Faculty of Economics and Business because of the universal and global economic nature that requires economic graduates besides mastering ecnomics also master one foreign language, in this case English language so that they can create excellent quality human resources.

In the science of teaching, teaching English for economics students falls into a category known as ESP (English for specific purpose) or in other words teaching English must be in accordance with the needs of students. Now what is happening at the Faculty of Economics and Business is teaching English at a standard level, which is only guided by five basic English skills, namely speaking, reading, listening and writing and has not met the criteria of English language specifically for economic students.

English that is taught to students at the Faculty of Economics and Business should be English that fits their needs so that they can equip themselves in the future after completing their education. For example, English in the Faculty of Medicine should be related to medical English or English for agricultural students should use material with agriculture vocabulary in it. The knowledge and expertise of English in their respective fields will give students the knowledge to understand the sources of knowledge in English that are appropriate to their fields.

The needs of English language can be obtained using the Needs Analysis method. Needs Analysis consists of questions concerning the information needed to design a syllabus that fits the needs of students, questions about what areas of English proficiency they are mastering or not mastering and also questions about what they need in learning.

Based on the explanation above, it is very interesting to discuss the analysis of English language needs of students at the Faculty of Economics and Business, Udayana University to find out what difficulties faced by the students in mastering English, to know what basic skills English is needed by the students and also what materials are considered necessary and do not need to be taught by students. 
This study aims to determine the difficulties faced by students in mastering English, basic English skills that need to be taught to students of the Faculty of Economics and Business, Udayana University, and material that needs to be taught to students of the Faculty of Economics and Business, Udayana University.

This research is expected to be able to provide input to the teaching syllabus of English in the Faculty of Economics and Business, University and also to improve the quality of English language teaching in the faculty.

\section{MATERIALS AND METHOD}

Needs analysis is often seen as the core of syllabus making for ESP. needs analysis is the basis of language teaching aimed at the creation and development of previous curricula (Dudley-Evans \& St John, 1998).

Furthermore, Hutchinson (1994) said to know the needs for learning English, it can be done through the Needs Analysis method. And furthermore, Hutchinson said the term need is the ability to understand and make the features that exist in the target situation and the target included learning. Needs Analysis can be divided into two, namely Target Needs and Learning Needs.

Target Needs refers to the needs or features of English linguistics which are the learning objectives. Target Needs can be divided into three needs (1) necessities are needs determined by what students must know in order to be effective in the target situation, (2) Lacks or deficiencies which are comparisons between students' knowledge or abilities with abilities that should be mastered by students, and (3) wants or desires are the needs desired by students. Weakness increases the difference between what the university wants and what students want. Inappropriate desires can affect the decline in student learning motivation.

While Learning Needs is a method for identifying needs related to the teaching environment which can be represented by the following questions; (1) how is English seen in terms of learning? (2) how do students learn English? (3) what teaching resources are available? (4) information about students, (5) where will English teaching be conducted? and (6) when will the English teaching begin?

The next step is to map information obtained from Needs Analysis and Learning Analysis into a syllabus design. The syllabus can also be called a curriculum whose understanding is a document that contains what needs to be learned (Hutchinson and Waters, 1994). To design the syllabus, the teacher must be able to ensure that the syllabus meets the wishes of students, Harding (2007, 10-11) presents three steps in making syllabus, namely designing the syllabus according to the needs of students by using the principles of teaching, determining the purpose and sequence of material and design the form of teaching to be applied to students, and including assessment procedures and evaluate the teaching given to students.

The research method is the steps taken in a scientific study. These steps are important to ensure the research takes place academically. In conducting this research, the research method to be applied is divided into three parts, namely data sources, methods and techniques of collecting data, and methods and techniques of analyzing data. Each part is presented in detail below.

The main data sources in this study are information obtained from questionnaires distributed to respondents, namely (1) student representatives from each study program at the Faculty of Economics and Business who know the purpose of learning English, (2) students as many as 41 people taken randomly from various study program at the Faculty of Economics and Business whose answers are considered to have been able to represent all students and (3) lectures of English courses at the Faculty of Economics and Business, Udayana University.

The data collection method used in this study is the survey method by distributing questionnaires that must be answered by respondents both respondents on the criteria of representatives of study programs, students and lectures. In addition to questionnaires, interviews will also be conducted to respondents.

The results of data analysis in this study are presented using quantitative descriptive and qualitative descriptive methods. Descriptive quantitative is done through the calculation of information obtained through questionnaires to be held for making it easy to do a description of the different information provided by the informant. The last step is to provide recommendations, namely English language material that needs to be taught in English Language courses at the Faculty of Eco-nomics and Business at Udayana University. 


\section{RESULTS AND DISCUSSION}

\subsection{DIFFICULTIES FACED BY STUDENTS IN MASTERING ENGLISH}

The first problem in this study was to find out what difficulties faced by students in mastering English language related to basic skills in mastering English. Questions in the questionnaire to analyze this problem were given to the two groups of respondents, namely students from each study program and also to English language instructors at the Faculty of Economics and Business, Udayana University.

Questions related to the problem of the first research are about basic English language skills which are considered difficult by students, even though the basic ability of English is very im-portant for future students. Respondents were asked to give a value to the list of difficulties encountered in mastering basic English skills provided in the table. The value given has a range of $1=$ easy, $2=$ medium, $3=$ difficult and $4=$ very difficult.

Table 1. Level of Difficulties faced by students in mastering Basic English Language Skills

\begin{tabular}{|l|l|}
\hline Skill & Score \\
\hline Reading & 2 \\
\hline Listening & 4 \\
\hline Speaking & 4 \\
\hline Writing & 3 \\
\hline Grammar & 3 \\
\hline Vocabulary & 3 \\
\hline Intonation & 4 \\
\hline
\end{tabular}

From table 1 above, students argue that listening, speaking, and pronunciation are the basic skills of English which are the most difficult for students to master. This was reinforced by the answers of students in the questionnaire who felt that what caused the difficulty in mastering the three basic abilities was because they rarely used English to communicate with each other, even if they used English to communicate, they found it difficult to listen to the speaker's accent.

The same thing was also conveyed by English language instructors at the Faculty of Economics and Business through the following table:

Table 2. Level of Difficulties faced by students in mastering Basic English Language Skills according to English language instructors

\begin{tabular}{|l|l|}
\hline Skill & Score \\
\hline Reading & 3 \\
\hline Listening & 4 \\
\hline Speaking & 4 \\
\hline Writing & 3 \\
\hline
\end{tabular}




\begin{tabular}{|l|l|}
\hline Grammar & 4 \\
\hline Vocabulary & 3 \\
\hline Intonation & 4 \\
\hline
\end{tabular}

From the table above it can be seen that according to the instructors, on average students are still very difficult to master the basic skills of English. According to the instructors, this is due to the lack of students using English or practicing English with their fellow students because they are only focused on learning when they get English lessons without self-repetition after the lesson.

\subsection{BASIC SKILLS THAT ARE DEEMED NECESSARY TO BE TAUGHT BY STUDENTS IN MASTERING ENGLISH}

The second question to answer the second problem in this research is that basic skills and material that are considered necessary to be taught by students in mastering English are only given to one group of respondents namely students because the answers from students are able to show students' desire to improve their basic abilities in mastery of English. Respondents are asked to give a value to the list of basic English skills that are deemed necessary provided in the table. The val-ue given has a range of $1=$ less, $2=$ moderate, $3=$ necessary and $4=$ very necessary.

Table 3. Basic English language competence of the students

\begin{tabular}{|l|l|}
\hline Skill & Score \\
\hline Reading & 3 \\
\hline Listening & 4 \\
\hline Speaking & 4 \\
\hline Writing & 3 \\
\hline Grammar & 3 \\
\hline Vocabulary & 3 \\
\hline Intonation & 4 \\
\hline
\end{tabular}

In accordance with the table above, three of the seven basic skills of English are considered necessary to be mastered by students which are indicated by score 3 . While four of the seven basic skills of English are listening, speaking, vocabulary and pronunciation are considered very necessary to master, which is shown by score 4 . Vocabulary is needed to be taught by students because there is still a lack of vocabulary in the economic field that is used in their teaching books. This is very much related to the teaching of ESP (English for Specific Purpose). Students feel that the vo-cabulary that is taught must be in accordance with their field, namely economy, not general English.

\subsection{CURRENT ENGLISH MATERIAL THAT IS CONSIDERED NECESSARY AND DOES NOT NEED TO BE TAUGHT BY STUDENTS IN MASTERING ENGLISH}

To answer the third problem, students are told to describe how they think about the material currently given. All students explained that there were still some materials given that were too general, not specific material related to the economic field that they would need in the future. The basic ability of 
English is very important for students going forward. Respondents were asked to provide necessary and unnecessary answers to the list of currently taught material provided in the table.

Table 4. Current English material that is considered necessary and unnecessary by students

\begin{tabular}{|l|l|}
\hline Meeting people & Yes \\
\hline Receiving and making a phone cell & No \\
\hline Company structures & Yes \\
\hline Product description & Yes \\
\hline Reporting & No \\
\hline Describing graphs & Yes \\
\hline Company result & Yes \\
\hline Comparing alternative & No \\
\hline Describing system and process & No \\
\hline Rules and regulation & No \\
\hline Calculating & Yes \\
\hline Repairing for a job interview & Yes \\
\hline
\end{tabular}

Of the 12 materials taught, students answer 5 materials; general material that does not need to be taught because it is not directly related to the economy and the material is the use of general English.

\subsection{ENGLISH MATERIAL THAT IS CONSIDERED NECESSARY TO BE TAUGHT BY STUDENTS IN MASTERING ENGLISH, ESPECIALLY THOSE RELATED TO ECONOMICS}

From question number three, students answer that the material that needs to be added in learning is public speaking and presentation (how to present), how to negotiate, and how to handle complaints and give solutions (how to deal with protests and provide solutions to problems). The material details for topics considered necessary by students are as follows:

Table 5. Topics and Materials

\begin{tabular}{|l|l|l|}
\hline No. & Topik & Materials \\
\hline 1. & Public speaking and presentation & Effective body language \\
& & Nervous management \\
& & Making the right-hand gesture \\
& & Making eye contact \\
\hline
\end{tabular}




\begin{tabular}{|l|l|l|}
\hline 2. & How to negotiate & Voice tone \\
\hline 3. & $\begin{array}{l}\text { How to handle complain and give } \\
\text { solution }\end{array}$ & $\begin{array}{l}\text { You can negotiate most things - but not everything } \\
\text { Negotiating is Not a win or lose situation } \\
\text { them finish. } \\
\text { Do your research }\end{array}$ \\
\hline $\begin{array}{l}\text { Ask question in a caring and concerned manner. } \\
\text { Put yourself in their shoes. }\end{array}$ \\
$\begin{array}{ll}\text { Apologize without blaming. } \\
\text { Ask the customer, "What would be an acceptable } \\
\text { solution to you?" }\end{array}$ \\
$\begin{array}{l}\text { Solve the problem or find someone who can solve it - } \\
\text { quikly! }\end{array}$
\end{tabular}

\section{CONCLUSION}

From the analysis that has been done it can be concluded that the difficulties in controlling the basic abilities of English include difficulties in mastering listening, speaking, grammar and pronunciation. In addition, according to the students the basic abilities that need to be possessed are listening, speaking, city vocabulary and pronunciation. Regarding the current material that still needs to be taught is meeting people, company structures, product descriptions, describing graphs, company results, calculating, repairing for a job interview, and what is considered unnecessary to teach from current material is receiving and making a phone call, reporting, comparing alternative, describing system and process, rules and regulation. Whereas the material needs to be added to the syllabus is public speaking and presentation, negotiation, and how to handle complaints and give solutions.

\section{REFERENCES}

Dudley-Evans, Tony and St. John, Maggie Jo. 1998. Developments in English for Spesific Purposes. Cambridge: Cambridge University Press.

Harding, K. 2007. English for Specific Purposes. Oxford: Oxford University Press.

Hutchinson, Tom and Waters, Alan. 1994. English for Spesific Purposes: A learning-centered approach. Glasglow: Bell \& Bain Ltd.

Tomlinson, B. 2008. English Language Teaching Materials. Cambridge: Cambridge University Press. 
